\title{
Environmental and social issues on energy policy in indonesia
}

\author{
Sudharto Prawata Hadi ${ }^{1, *}$, Bulan Prabawani², and Hartuti Purnaweni ${ }^{3}$ \\ ${ }^{1}$ Faculty of Social and Political Sciences, and Graduate Program of Environmental Studies, Diponegoro University, \\ Semarang, Indonesia \\ ${ }^{2}$ Faculty of Social and Political Sciences Diponegoro University, Semarang, Indonesia \\ ${ }^{3}$ Faculty of Social and Political Sciences, and Graduate Program of Environmental Studies, Diponegoro University, \\ Semarang, Indonesia
}

\begin{abstract}
One crucial problem faced by Indonesia is the dependence on fossil energy reaching to $93,3 \%$, while the share of renewable energy is only $7,7 \%$. This causes two implications. Firstly, Indonesia is at the situation of insecurity energy due to the limitation of the availability of fossil energy. Since 2004, Indonesia is net importer oil country. Secondly, the use of fossil energy creates CO2, a component of green house gases stimulating global warming and climate change. One strategy to deal with this problem is by implementing new energy system consisting of developing renewable energy and energy efficiency.

This paper observes the impact of the use of fossil energy, the measures taken to deal with these problems and the issues of implementing the measures. This research relies on secondary data available at the Ministry of Energy and Mineral Resource, Ministry of Environment and Forestry specifically at by Proper Secretariat, and other relevant sources.
\end{abstract}

Key words: fossil energy; insecurity energy; global warming;new energy system.

\section{Introduction}

As mentioned at Presidential Decree 21 of 2017 on General Plan of National Energy that energy resource is no longer treated as export commodity but as a national development capital for achieving self-managing energy, to ensure energy availability and to achieve domestic energy need, to optimize integrated and sustainable energy management, to improve energy efficiency, to ensure afair and equal access, to develop technology competence of industrial energy and energy service, to create employment opportunity and to control the impact of climate change and to ensure environmental sustainability [1]. From the perspective of social and environment, the policies need to be underlined are efforts to develop renewable energy, energy efficiency, fair and sustainable energy management.

\section{Environmental and Social Impacts}

Exploration and exploitation of fossil energy specifically coal as energy source creates environmental and social impacts. As quoted by Kompas Daily Newspaper (May 30, 2018) most mining companies in Aceh did not implement reclamation [2]. Bad mining management stimulate forest degradation, loss of wildlife habitat, degradation of river basin and escalation of social conflict. Similar cases occur in Kalimantan where provincial and local government prioritize mining sector as engine of economic growth. In South Kalimantan there are 813 mining permit with 6,4 million hectare. In East Kalimantan with the area of 12,7 million hectare, 5,2 million hectare $(46 \%)$ is allocated for mining with the number of mining permit reach to 1400 where 232 mining companies left the area without any reclamation. Agrarian conflict in East and West Kalimantan reach to 126 cases [3].Environmental degradation caused by mining activities place environmental quality index in South Kalimantan are at the lowest ranking among Kalimantan provinces and at the rank of 26 among 35 provinces in Indonesia.

\section{Insecurity Energy}

Since 2004, Indonesia has been a net oil importer country. The need of fuel oil reachto 1,6 million barrel per day while the production capacity only 800.000 barrel per day [4]. The increase of energy consumption has been stimulated by economic and population growth, inefficient use of energy and government subsidy for energy consumption.Energy potential of fossil energy show that petroleum reserve leaving 12 year, natural gas

\footnotetext{
*Corresponding author: sudhartophadi@yahoo.co.id
} 
33 year, coal 82 year. Based on data of General Plan of National Energy (2017), 79,3\% coal produced is being exported to other countries while coal reserve only $3,1 \%$ of world reserve [5].

\section{The impact of Climate Change}

The use of fossil energy causes the increase of $\mathrm{CO} 2$, a componentof green house gases stimulating global warming and climate change. Data in 2017 showed that CO2 emission increased from 433,3 million ton in 2013 to be 464,4 million ton in 2014. It was also true for CO2 emission per capita which was 1,8 ton/ capita in 2013 to be 1,9 ton/ capita in 2014 [5]. Indonesian government promised to reduce green house emission at $26 \%$ in 2030 as business as usual and $42 \%$ with international assistance.Based on data released by World Energy Report (2006), total emission of CO2from energy sector reach to 286 million ton. Emissionwill increase twice every twelve year in which coal is the largest carbon source [6] Total contribution of $\mathrm{CO} 2$ emission from developing countries including Indonesia predicted to increase in 2020 reach to 18365 million ton from world total emission at 38214 million ton. The impact of global warming and climate change include sea level rise, sea temperature rise, air temperature rise, increase of rainfall, evaporation and tropical storm.As archipelagic country with second longest coast line where $65 \%$ population live at coastal area, Indonesia is at the vulnerable condition affected by the impact of climate change. In addition, agriculture, animal husbandry and fishery will be severely affected by climate change.

\section{New Energy System}

New Energy system is one strategy dealing with energy problem consisting of development of renewable energy and energy efficiency. The following table shows the abundance of renewable energy and its installed capacity

Table 1.Renewable Energy Potential in Indonesia

\begin{tabular}{|l|l|l|}
\hline \multicolumn{1}{|c|}{ Type } & \multicolumn{1}{c|}{ Potential } & \multicolumn{1}{c|}{$\begin{array}{c}\text { Installed } \\
\text { Capacity }\end{array}$} \\
\hline Hydro & $75.091 \mathrm{MW}$ & $4,826 \mathrm{MW}$ \\
\hline Geo-thermal & $28.910 \mathrm{MW}$ & $1438,5 \mathrm{MW}$ \\
\hline Ocean & $17,989 \mathrm{MW}$ & $0,3 \mathrm{MW}$ \\
\hline Bio-energy & $32.654 \mathrm{MW}$ & $1671 \mathrm{MW}$ \\
\hline Solar & $\begin{array}{l}4.8 \mathrm{kWh} / \mathrm{m} 2- \\
\text { day }\end{array}$ & $78,5 \mathrm{MW}$ \\
\hline Wind & $3-6 \mathrm{~m} / \mathrm{sec}$ & $3,1 \mathrm{MW}$ \\
\hline $\begin{array}{l}\text { Mini \&Mikro } \\
\text { hydro }\end{array}$ & $19,385 \mathrm{MW}$ & $197,4 \mathrm{MW}$ \\
\hline
\end{tabular}

Source: General Plan of National Energy (RUEN), 2017 [7]

From this potential of renewable energy it is necessary to accelerate utilizing them to meet the target of renewable energy share. Indonesian government determined that the target of renewable energy contribution to national energy mix is expected to be $23 \%$ in 2025 and $50 \%$ in 2030. However, this plan went slowly. In 2006 , the share of renewable energy was $5 \%$ and in
2018 it only reach As compared to fossil energy, renewable energy is more environmentally friendly, creates employment opportunity and increase income for local people. However, there are many issuesrelated to renewable energy including a diverse geography, uncertain regulation, unclear market, weak coordination among relevant agencies causing the high price of renewable energy.According to Widodo (2018) the policy of developing energy in Indonesia is based on low cost and ignore social and environmental cost as mentioned about the impact of fossil energy [8].

\section{Energy Efficiency}

Another aspect of new energy system is energy efficiency through change of people's behavior and institutions in consuming energy. One program showing the significant contribution for energy efficiency is business performance rating (proper) initiated by Ministry for Environment and Forestry [9]. To achieve a green and gold ranking, participating industries must adopt a cleaner productionprinciples which successfully deal with environmental pollution andcreate energy efficiency, water use, waste generation, emission reduction as shown at the following table.

Table 2. Eco-efficiency of Proper Participating Industries

\begin{tabular}{|l|l|l|l|}
\hline Year & $\begin{array}{l}\text { Energy (giga } \\
\text { joule) }\end{array}$ & Water $\left.\mathbf{( m}^{\mathbf{3}}\right)$ & $\begin{array}{l}\text { Emission } \\
\text { (tonne CO2 } \\
\text { eq) }\end{array}$ \\
\hline 2016 & $249,808,268$ & $447,463,288$ & $75,663,410$ \\
\hline 2015 & $919,098,110$ & $533,128,233$ & $48,193,255$ \\
\hline 2014 & $26,105,806$ & $491,815,713$ & $48,076,583$ \\
\hline
\end{tabular}

\begin{tabular}{|l|l|l|}
\hline Year & $\begin{array}{l}\text { Hazardous } \\
\text { Waste(tonne) }\end{array}$ & $\begin{array}{l}\text { Non- } \\
\text { Hazardous } \\
\text { Waste } \\
\text { (tonne) }\end{array}$ \\
\hline 2016 & $6,444,846$ & $3,245,604$ \\
\hline 2015 & $4,786,034$ & $9,419,229$ \\
\hline 2014 & $3,205,649$ & $11,908,001$ \\
\hline
\end{tabular}

Source: Proper Secretariat, 2017[9]

Table 2 shows thehuge energy efficiency and emission reduction resulted from Proper. However, the number of industries participating at Proper are less than $10 \%$ compared the number of industries potentially cause significant environmental impacts reaching to 25000 industries.

\section{Conclusions and Recommendations}

1. The dependence on fossil energy bring implications on insecurity energy, environmental and social impacts, andglobal warming and climate change.

2. New energy system is a the strategies to deal with these problems consisting of developing renewable energy and energy efficiency

3. The high price of renewable energy need to be dealt by providing subsidy, simplification of procedure 
4. and incorporation of environmental and social cost of the use of fossil energy

5. The development of renewable energy is able to support economic growth, fairness, justice, equity and environmentally friendly

6. In relation to energy efficiency, it is required need to adopt change of behavior in consuming energy both individually (household, people's behavior) and institutionally (industry, government, private sector,)

7. It is required to obliged industries potentially cause significant environmental impacts to participate at Proper for energy efficiency and emission reduction

\section{References:}

1. Government Regulation no 79 of 2014 on Energy National Policy (2014)

2. Unplug 108 Mining Permit.Kompas Daily Newspaper. May 30 (2018)
3. Kalimantan Regional Meeting of Environment and Forestry, Balikpapan, May 2, 2018

4. Head of Research and Development, Ministry of Energy and Mineral Resource, Republic of Indonesia. Key note speech delivered at Focus Group Discussion on Developing bio-energy. Jakarta, August 10(2018)

5. Presidential Decree No 22 of 2017 on General Plan of National Energy (2017)

6. World Energy Report(2006

7. Presidential Decree No 22 of 2017 on General Plan of National Energy (2017)

8. W.W.Purwanto. 2018. Assessing Renewable Energy Development in Indonesia.Status Barriers and Opportunities. BungaRampaiInovasi. Jakarta: DewanRisetNasional (2018)

9. Ministry of Environment and Forestry, Proper Secretariat. Proper Report 2017 